\title{
INTRODUCTION OF A NEW EXTRA LONG EXTRA FINE EGYPTIAN COTTON PROMISING CROSS
}

\section{EL-FEKI, T.A., M.A. ABD EL-BAKI, A.A.A EL-AKHEDAR, M.N. NAZMEY, M. A. ABOU EL-YAZIED AND AZIZA M. SULTAN}

\author{
Cotton Research Institute, ARC, Dokki, Giza
}

(Manuscript received 14 May 2009)

\begin{abstract}
The new promising cross Giza 77x pima s6 is an extra long extra fine Egyptian cotton promising cross while was produced through artificial hybridization between the parents Giza.77 and Pima $\mathrm{S}_{6}$. The new promising cross is characterized with its extra fine, extra long and very strong fiber about 46-5 gram / tex, 36.5- $38 \mathrm{~mm}$ upper half mean, 3.3 micronaire reading $105-120$ millitex for hair weight and over 3000 yarn strength. Also the lint percentage is about $33-35 \%$. This promising cross is characterized with high yield. This promising cross is characterized by its resistance against Fusarium oxysporum and $f$. vasinfectum. This promising cross could be the best alternative to Giza 45 and Giza 87.
\end{abstract}

\section{INTRODUCTION}

Cotton Research Board was established in 1919 ( Cotton Research Institute now). During that time, Sakel variety covered the cotton area in Delta, while Ashmoni variety coverd area in Middle and Upper Egypt. Therefore, from these two varieties (Sakel and Ashmoni) most Egyptian cotton varieties have been derived through individual selection. Many varieties like Giza 7 and Sakel 4 were good examples. Varietal hybridization was first employed in 1921 between Ashmoni and Sakel. The first hybrid was obtained from Giza 12 (wafer) that surpassed Giza 7 in yield and earliness but its fiber was inferior in quality. The variety Giza 29 (Karnak) was introduced by hybridization where it dominated in Delta farms for 15 years and surpassed other long staple varieties for its yield superiority over Sakel. Afterwards, the variety Giza 36 (Menoufi) was developed and was propagated in 1942 to replace Giza 7. Menoufi was superior in length and strength Al-Didi (1972). Recently a series of extra long staple varieties have been produced and the latest of which Giza 70, Giza 76, Giza 77, Giza 87, Giza 88 and Giza 92, El-Moghazi et al.( 1984), Hanem et al. (2003) and El-Helow et al. (2003). In this investigation, the breeding and production of new promising cross which is extra long extra fine staple will be discussed. 


\section{MATERIALS AND METHODS}

Artificial hybridization between Giza 77 and Pima S $_{6}$ was carried out during 1990 season at Giza Experiment Station. Giza 77 lint is of creamy color and was characterized by high strength, long fiber and high yield, whereas Pima $S_{6}$ was characterized by earliness and high yield. The $F_{1}$ hybrid seed was grown in the second season. Beginning with the $F_{2}$ until $F_{11}$ generation selection had been carried out at Sakha Experimental Station. The selected families from the $F_{5}$ generation of the hybrid were evaluated through trials A and B at Sakha and at different locations of Delta to select most the promising ones that excelled the commercial varieties of same category. Progeny of the promising maternal families in the later generations that were selected from the nursery were grown in an isolated field to maintain the selected strains as breeding nuclei were included in a yield trial $A$ to test the new promising family Randomized Complete Block Design with six replications was used in each experiment with five rows were included in each plot. The row was four meters long, $60 \mathrm{~cm}$ a apart and $20 \mathrm{~cm}$ between hills. The hills were thinned to two plants. The yield was obtained from the three middle rows of plot. In this investigation the following characters were considered :

1- Seed cotton yield (S.C.Y/F) is estimated as weight of seed cotton yield in kentar per faddan.

2- Lint yield (L.C.Y/F) is estimated as weight of lint cotton yield in kentar per faddan.

3- Boll weight, is the average weight in gram of 50 sound opened bolls picked at random from the first and fifth row of plot.

4- Lint percent (L\%) is the amount of lint an seed cotton sample expressed in percentage.

5- Fiber fineness and maturity in micronaire reading (M.R).

6- Upper half mean in mm measured by HVI.

7- Hair weight (H.W) in terms of millitex (10-8 g/tex).

8- Yarn strength (Y.St.) is the product of lea strength $x$ yarn count $(60 \mathrm{~s}$ carded and 3.6 twist multiplier) measured by Good Brand tester. The analysis of variance was calculated according Snedecor (1956) and Leclierge et al. (1962) . 


\section{RESULTS AND DISCUSSION}

\section{Breeding methodology}

In 1990 season hybridization was carried between the two parents G.77 and Pima $\mathrm{S}_{6}$ of $G$. barbadense, L. at Giza Agric. Exp. Sta. Whereas, the $F_{1}$ hybrids seed and later generations were grown from 1991 season at Sakha Exp. Sta. Selection through pedigree method was applied starting from $F_{2}$ generation up to $F_{11}$ generation in breeding nursery. The outcome results of preliminary trial $A$ and the advanced trial $B$ yield evaluation at Sakha and different location of Delta Egypt for seven seasons proved that the three maternal Families, $F_{11} 1261 / 2001,1262 / 2001$ and 1266/2001 had almost excelled the check varieties (G.87 and G.45). Fig (1) shows the steps of pedigree method from hybridization to $F_{11}$ generation and through trial $A$ and $B$ for evaluating the yield and other traits and the interaction between genotypes and environment according to Hays (1955). The combined data of trial B in seven location in Delta Egypt (Kafr El-Shekh, El-Behira, El-Dakhlia, Demiat, Monofaia, Sharakaia and Elgarabia) for yield and its components are presented in Table (1). The data of yield showed that the three selected families of the cross Giza 77 x Pima $S_{6}$ significantly surpassed the check varieties Giza 45 and Giza 87 of the extra fine extra long staple category. The data in Table (1) indicated that mean value of three selected families seed cotton yield significantly exceeded Giza 45 with a range of 4.45-4.88 ken tar/faddan while they exceeded significantly Giza 87 of range $1.29 \quad-1.72$ kentar/faddan. Moreover the mean lint cotton yield was in agreement with those of seed cotton yield and surpassed Giza 45 by a range 5.17-5.87 K/F while they surpassed Giza 87 by a range of $1.88-2.38 \mathrm{k} / \mathrm{f}$. The results of lint percentage of the three promising families showed higher lint percent values compared with G.45 and G. 87 varieties. Table (1) regarding earliness index, the results indicated that the three selected families were earlier than G.45 and did not differ from 87. For boll weight, the three families exhibited value while surpassed Giza 45 and Giza 87. There were significant differences between the values of the three families and the two commercial varieties G.45 and G.87 in all examined characters except for U.H.M which showed slight differences. All families showed results in agreement with combined data for every single location Table (9). The results of micronaire and hair weight were very close to Giza 45 and Giza 87. So these families of this cross appeared to be similar to the commercial varieties Giza 45 and Giza 87 these results in agreement with those obtained by El-Feki et al. (2005) who indicated that the promising cross Giza 77 x Pima $S_{6}$ may replace the extra long varieties Giza 45 and Giza 87 and was also in agreement with those obtained by El-Sayed et al. (2008). 
The similarity and taxonomic distance between the maternal families and Giza 87 hierarchical clustering was applied to determine the relative genetic diversity and genetic distance within the tested germplasm. Results are shown by the dendrogram in Fig (2). The linkage dendrogram provides visual idea about clustering and variability exhibited between those genotypes. Fig (2) and Table (2) showed that the two maternal families $1261 / 2001$ and $1262 / 2001$ were joined with $\mathrm{G} .87$ by similarity level $98.14 \%$ and taxnomic distance 5.65 , while the third family 1266/2001was farther than the two families. These result indicated that progeny of two families 1261/2001 and $1262 / 2001$ could be used to produce the lives of new a variety.

Table (3) shows the comparison between the new variety and the two commercial varieties G.45 and G.87. The combined results for the seven traits indicated that the new promising cross surpass of the two varieties for seed and lint cotton in yield through three seasons 2006, 2007 and 2008 while the other character did not differ significantly.

\section{Steps of introducing the strains of the new promising cross}

Fig (3) shows the steps of introducting three strains first, second and third breeder seeds. In 2004 season 50 plants were selected from the progeny of the two maternal families 1261/2001 and 1262/2001 cultivated in anisolated field. These plant represent $F_{14}$. In season, 2005 two groups of 50 plants were selected to cultivate as the individual plants from selfed seed, while natural seed were cultivated as bulk. The selfed seed of the second group was planted bulkily in 2005 forming 50 nucleolus /2005, while their natural seed were cultivated as natural nucleolus.

In season 2006, 20 out of 50 nucleolius / 2005 were selected to be cultivated as 20 nucleus from selfed nucleoli and their natural nucleolus were tested for yielding trial of new variety.

Table (4) shows the range of the quality characters " ie " spinning strength, fiber fineness, U.H.M fiber strength and lint percentage which characterized nucleolis. Table (4) also reveals the selection limits of the nucleolus /2005 forming each 20 nuclei /2006 indicating that selection level:

1. Yarn strength over 3280.

2. Fiber fineness range of 105 to 115 m.tex and 2.8- 3.1 mic.

3. Upper half mean of fiber not less than 36 m.m.

4. Fiber strength over 47.0 g.tex.

5. Lint percentage over $33.6 \%$

Yield trial was carried out to evaluate the uniformity between 20 nuclei /2006. Table (5) indicating that the differences between 20 nuclei were insignificant for all characters indicating the homogeneity between nucleis. Four 
higher arrangement nuclei were selected and their seeds were mixed to form the first breeder seeds (strain /2006) .The character of these nuclei are shown in Table (6).

The progeny of 50 plants were cultivated as individual plants in year 2005 the two groups of 50 plants were selected to be cultivated in the 2006 season. The first group were cultivated as individual plants from selfed seeds and bulkily from natural seeds. The second group were cultivated as selfed nucleoli /2006 and natural seeds were cultivated as natural nucleolie. In season 2007, 23 out of 50 nucleolie were selected to be cultivated as nuclei from selfed seeds and the natural seeds of these nuclei were evaluated through the yield trial.

Table (4) clears the selection limits of nucleoli/2006 forming19 nucleis /2007 as follow:

1. Yarn strength over 3285.

2. Upper half mean of fiber not less than 35.9 m.m.

3. Fiber fineness rangs from 105 to $124 \mathrm{~m}$.tex and 3.0 to 3.3 mic.

4. Fiber strength over 50.5 g.tex.

5. Lint perentage over $32.11 \%$

Nine teen nuclei were selected to be cultivated as nuclei and were tested in a yield trial yield. The analysis of variance showed insignificant differences indicating genetic homoginity for strains of the new variety promising cross. So 5 higher arrangement of nuclei were selected to form the second breeder seed (strain 2/2007), these nucleis are shown in Table (7).

The progeny of 50 plant were cultivated as individual plant in 2006 , the two groups of 50 plants that were selected to be cultivated in season 2007. The first group were cultivated as individual plants from selfed seeds and bulkily from natural seeds. The second group cultivated as selfed nucleolie/2007 and natural seeds were cultivated as natural nucleoli. In season 2008, 23 out of 50 nucleolis were selected to be cultivated as nucleoli from selfed seed and yielding trial from natural seeds to be were tested in yield trail.

The selection level would be:

1. Yarn strength over 3300.

2. Fiber fineness range of 107- 126 m.tex and 2.9- 3.4 mic.

3. Upper half mean of fiber not less than $36.6 \mathrm{~m} . \mathrm{m}$.

4. Fiber strength over 49.0 g.tex.

5. Lint percentage over $31.6 \%$

The analysis of variance in Table (5) indicated that the differences were insignificant suggesting that the strains of new variety were uniform and exhibited 
genetic homogeneity then 5 higher arrangement of nuclei were selected to form third breeder seed by mixing their seed together. These nucleie are shown in Table (8). So, it could be considered to be as foundation seed.

\section{Evaluation of the new promising cross}

Comparative studies were held between the new promising cross and the commercial varieties G.45 and G.87 which are characterized by extra long staple length and extra fineness for lint yield, seed cotton yield, boll weight and earliness index. The data was extracted from the yield trial B was grown at four locations representing Delta regions Egypt in three season 2006, 2007 and 2008. The data in Table (9) show the average of the new promising cross and two cultivated varieties in season 2006 indicated that the new promising cross with excess exceeded by 1.51 and 2.94 kentar/faddan over the average of Giza 87 and Giza 45, respectively, for seed cotton yield while the increases were 1.94 and 3.54 kentar/feddan for lint yield over Giza 87 and Giza 45, respectively. The increase was in three location that were cultivated in season 2006. While in two seasons 2007 and 2008 the new promising cross did not differ significantly from the average of Giza 87 , while the new promising cross had increases of 1.64 and 1.77 kentar/Faddan for seed cotton yield than G.45 in two seasons 2007 and 2008, respectively. Whereas the excess of lint yield over Giza 45 were 1.97 and $0.93 \mathrm{kentar} / \mathrm{faddan}$ in seasons 2007 and 2008, respectively. The average seed and lint cotton yield in all location that were cultivated that the 2008 indicated that the averages of new promising cross surpassed the average of Giza 87 in all locations except for Dakahlia. Boll weight results in Table (9) showed inconsistent differences between the new promising cross and the two cultivars Giza 87 and Giza 45. Moreover these differences were always insignificant for lint percentage. Results in Table (9) indicated that the average of the new promising cross surpassed overall averages of cultivated varieties but insignificant differences. With regard to earliness index the result showed insignificant difference between the new variety and cultivated varieties.

The present study of the new promising cross had proved its superiority over extra fine extra long staple varieties Giza 45 and Giza 87. This finding was in agreement with those obtained by El-Sayed et al. (2008) concerning all economic traits particularly lint yield. The new promising cross could be the best alternative of Giza 45 and Giza 87.

As perceived in this study, the new promising cross has excelled Giza 45 and Giza 87 in the average of lint yield per faddan, therefor replacement of this new promising cross might lead to increase in the yield of extra long staple extra fine varieties and make this cross compete the other long staple varieties in marketing. 


\section{CONCLUSION}

It could be concluded that the promising cross Giza $77 \times$ Pima $S_{6}$ produced more seed - cotton and lint cotton yield than the commercial varieties Giza 45 and Giza 87 of the same category. Also it surpassed the two varieties for average weight of 50 bolls and slightly exceeded the two commercial varieties for lint percentage. Concerning fiber quality the promising cross (Giza $77 \times$ Pima $\mathrm{S}_{6}$ ) had the same values of the category for extra long staple extra fine with $98 \%$ level of similarity with G.87. The plants of the promising cross were highly resistant against fungi disease Fusarium wilt (Fusarium oxysporum). So the selected strains of this cross could be used as a new genetic source for high yielding ability extra fine extra long staple and could replace Giza 87.

\section{ACKNOWLEDGMENT}

The authors express their deep gratitude to staff of the extra long staple branch breeders and staff of cotton breeding section for their co-operation valuable help and assistance. 


\section{REFERENECES}

1. Al-Didi, M. 1972. History of Egyptian cotton varieties Egypt cotton Gizet 5836-56.

2. El-Feki, T.A., M.G.I. Beheary and A.A.A. El-Akhdear. 2005. Technological and genetical estimates for yield and fiber properties of some extra-long Egyptian cotton promising genotypes. J. Agric. Res. Tanta Univ. 31 (1) $32-45$.

3. El-Helow, Sayda S. , Hanam, A.M , A.A.M . Awad and M.A.M. Allam. 2003. Breeding potential of promising hybrid Giza $84 \times(G .74 \times G .68)$ of the extra long staple cottons. Egypt. J. Agric.Res.,81 (2) , 647 -657.

4. El-Moghazi, M.A.A., Sallam and A.A. El-Gohary. 1984. Introduction of extra long staple Egyptian cotton variety "Giza 77" Agric. Res. Rev. Egypt, 62: 1322.

5. El-Sayed, M.M., A.M. Abd EL-Bary, H.M. Mohamed and M.A. Abou-El-Yazied. 2008. Yield and quality improvement trends in Egyptian cotton. Egypt. J. Agric. Res. 86 (1) 195 - 206.

6. Hanem A. El-Salam, Sayeda, S. El-Helow, A.A.M. Awad and M.A.M. Alam. 2003A. Evaluation of the extra long staple Egyptian cotton variety Giza 88. Egypt J. Agric. Res. 81(1) 163 - 176.

7. Hanem A. El-Salam, Sayeda, S. El-Helow and M.A.M. Alam. 2003B. Evaluation of the extra long staple Egyptian cotton variety (Giza 87) Egypt J. Agric. Res. 81 (1), $177-191$.

8. Hays, H.K., Immer and D.C. Smith. 1955. Methods of plant breeding $2^{\text {th }}$ ed MC Graw-Hill Book Co., New York.

9. Leclerge, E.L., W.H. leonard and A.G.Clork. 1962. Field plot technique Burgess ppl.Co.

10. Sendecor, G.W. 1956. Statistical Methodes Iowa Univ. Press Ames. Iova USA. 


\section{استنباط صنف قطن جديد من طبقة الأصناف فائقة الطول فائقة النعومة}

طلعت احمد الفقى ،محد عبد الجليل عبد الباقى ، عادل عبد العظيم الأخضر

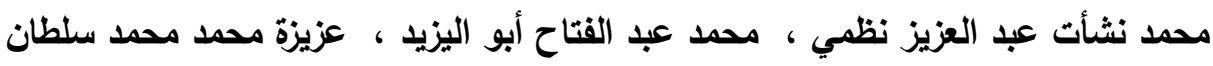

$$
\text { معهُ بحوث القطن - مركز البحوث الزراعية - الجيزة }
$$

يعتبر الهجين المبشر ج XV × بيما سج احد أصناف طبقة فائق الطول فائق النعومة واستتبط

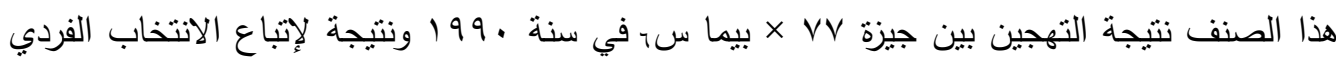
المنسب حتى الجيل الخامس وبداية من الجيل الخامس تم تقيمه في تجارب أولية للمحصول وفى السنة التالية نم تقييمه في تجربة (ب) في عدة مناطق في الدلتا واستمر ذلك حتى الجيل الحادي عشر ثم تم تُبن الحصول على ثلاثة عائلات أمية لهذا الهجين وتم أجراء التحليل العنقودي عليها فكان التشابه بين

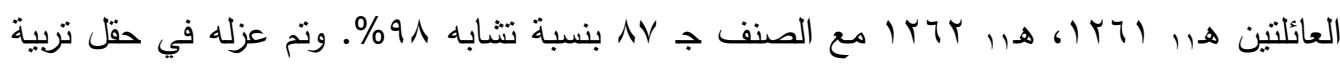

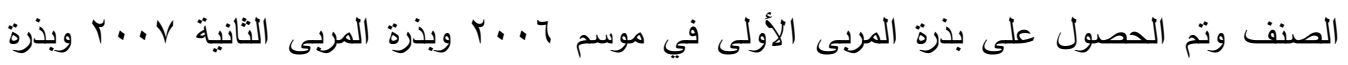

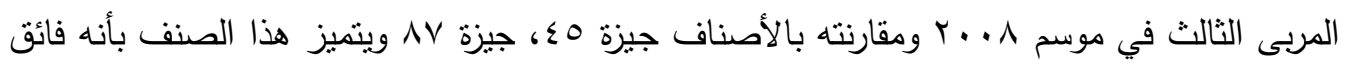

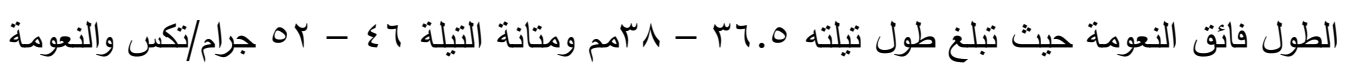

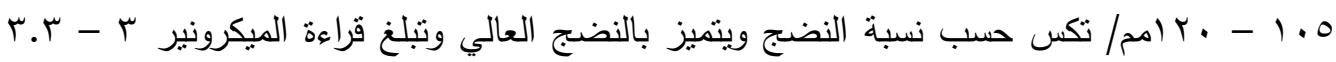

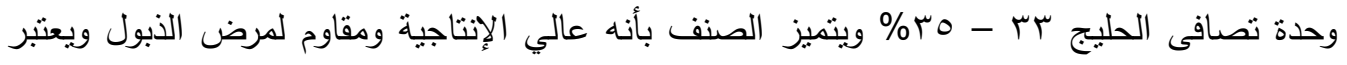
هذا الصنف بديلا جيد للصنف جيزة 0؛ أو جيزة NV حيث لا يختلف معهما في صفات الجودة ولكنه يتقوق عليهما في الإنتاجية. 